\title{
INNER PEACE OF DELINQUENT ADOLESCENTS FROM THE ISLAMIC PSYCHOLOGY PERSPECTIVE
}

\author{
Ati Kusmawati \\ Universitas Muhammadiyah Jakarta \\ Ati2051976@gmail.com
}

\begin{abstract}
This paper explains theoretically related to adolescent inner peace with delinquent behavior in terms of psychological perspective. It can be concluded that adolescents with deluent behavior in order to have inner peace are expected and there must be social support from all parties including (1) intensive school communication with parents to determine the condition of adolescents (students) when at school; (2) strong learning support from parents, teachers and schools is expected because adolescents with delinquent behavior need more attention so that the learning process can run well and have good values of character; (3) the availability of facilities that help adolescents to get changes such as through a religious approach (reading the Koran and an intensive study of the meaning of the Koran) this is done in stages and requires considerable time and the teacher must have patience in carrying out this task.
\end{abstract}

Keywords: inner peace, adolescent, delinquency behavior, Islamic psychology perspective

Abstrak: Tulisan ini menjelaskan secara teoritis terkait kedamaian bathin remaja denga perilaku delinkuen ditinjau dari presfektif psikologi. Dapat disimpulkan bahwa remaja dengan perilaku delikuen agar memiliki kedamaian bathin diharapkan dan harus adanya dukungan sosial dari semua pihak diantaranya (1) adanya komunikasi sekolah dengan orangtua secara intensif untuk mengetahui kondisi remaja (siswa) ketika di sekolah ; (2) dukungan belajar yang kuat dari orangtua, guru dan sekolah sangat diharapkan karena remaja dengan perilaku delikuen memerlukan perhatian yang lebih agar proses belajar dapat berjalan dengan baik dan memiliki nilai-nilai budi pekerti yang baik pula; (3) ketersediaan fasilitas yang membantu remaja untuk mendapatkan perubahan seperti melalui pendekatan agama (membaca al-Qur'an dan adanya kajian dari makna al-Qur'an secara intensif) hal ini dilakukan secara bertahap dan memerlukan waktu yang cukup lama serta guru harus memiliki kesabaran dalam melaksanakan tugas ini.

Kata Kunci: Kedamaian batin, Remaja, Perilaku Delinkuen, Persfektif Psikologi Islam

\section{Pendahuluan}

Setiap individu menginginkan hidup dalam kedamaian, baik dari luar dirinya maupun dalam dirinya. kedamaian bathin merupakan bingkai kebahagiaan dalam hidup. Setiap orang

44 NUANSA Vol. XII, No. 1, Juni 2019 menginginkan untuk menjadi tenang dalam pikiran terkait dengan kebahagiaan, kedamaian bathin dan kepuasan. Ketenangan pikiran adalah deskripsi dari disposisi yang bebas dari efek stres. Begitu pula dengan remaja dengan perilaku 
delinkuen. Mereka termasuk kedalam bagian inklusi sosial (kaum rentan). Remaja merupakan sosok yang unik dengan beragam pola dan tingkahlaku yang ada dan dimunculkan. Hampir semua remaja mengalami masa perubahan baik fisik maupun emosi. Menurut Erickson masa remaja adalah masa terjadinya krisis identitas atau pencarian identitas diri. Gagasan Erickson ini dikuatkan oleh James Marcia yang menemukan bahwa ada empat status identitas diri pada remaja yaitu identity diffusion/ confussion, moratorium, foreclosure, dan identity achieved (Santrock, 2003, Papalia, dkk, 2001, Monks, dkk, 2000, Muss, 2001). Karakteristik remaja yang sedang berproses untuk mencari identitas diri ini juga sering menimbulkan masalah pada diri remaja. Remaja adalah masa yang penuh dengan permasalahan. Statemen ini sudah dikemukakan jauh pada masa lalu yaitu di awal abad ke-20 oleh Bapak Psikologi Remaja yaitu Stanley Hall. Pendapat Stanley Hall pada saat itu yaitu bahwa masa remaja merupakan masa badai dan tekanan (storm and stress) sampai sekarang masih banyak dikutip orang. Remaja memiliki rasa ingin tahu yang tinggi dan ketika kemampuan kognitif mereka mencapai kematangan, diharapkan dan melakukan kritik terhadap masyarakat mereka, orang tua mereka dan bahkan terhadap kekurangan diri mereka sendiri (Myers, 1996). Menurut Piaget (Desmita, 2009) bahwa perkembangan kognitif remaja bahwa pemikiran masa remaja telah mencapai tahap pemikiran operasional formal (formal operational thought), yaitu suatu tahap perkembangan kognitif yang dimulai pada usia kira-kira 11 atau 12 tahun dan terus berlanjut sampai remaja mencapai masa tenang atau dewasa. Pada tahap ini anak sudah dapat berpiki secara abstrak dan hipotetis. Pada masa ini, anak sudah mampu memikirkan sesuatu yang akan atau mungkin terjadi sesuatu yang abstrak.

Munculnya remaja yang berperilaku delinkuen berasal dari diri sendiri seperti kon- sep diri, kontrol diri/emosi yang lemah,seorang remaja yang tidak bisa membedakan perbuatan baik dan tidak baik akan terseret pada perilaku "nakal". Berasal dari luar yaitu kurangnya perhatian dan kasih sayang dari orang tua, pola asuh yang salah, media sosial, gaya hidup akibat pengaruh lingkungan dan teman serta komunitas, sehingga mereka tidak mendapatkan atau menemukan apa yang mereka inginkan. Ada pepatah lama mengatakan kasih sayang adalah pelajaran termurah. Apabila seorang anak tidak diberikan perhatian khusus oleh orang tuanya yang merupakan lembaga utama pembelajaran seorang anak, maka anak tersebut sulit mendapatkan pelajaran mengenai hal yang boleh diperbuat atau hal yang dilarang. Seorang anak yang seharusnya meniru atau mencontoh hal-hal baik orang tuanya namun sulit didapatkan maka anak lebih memilih kedunia luar tanpa pengawasan orang tua. Sehingga tidak heran anak akan berperilaku menyimpang. Untuk itu diperlukan kontrol orang tua secara baik.

Penelitian Sigfusdottir, et al (2010) dijelaskan para remaja yang dirinya pernah diganggu atau disakiti oleh sekelompok orang, atau pun pernah menyerang kelompok lain dengan kelompok yang diikutinya, mereka akan menjadi remaja yang sama kepribadiannya dan akan berpengaruh pada keputusan untuk terlibat dalam kenakalan remaja. Akibat korban bullying mempengaruhi baik korban dan pelakunya untuk terlibat dalam kenakalan secara langsung karena adanya luapan kemarahan sebagai reaksi timbal balik, hal inilah yang menyebabkan perilaku kenakalan. Kesimpulannya, kemarahan akibat korban bullying secara langsung berhubungan dengan adanya perilaku kenakalan. Sedangkan untuk memeriksa perilaku bullyingmenyebabkan kenakalan ketika mengawasi adanya kemungkinan temuan pengaruh pada variabel latar belakang, peneliti menguji pemodelan struktural. Hasil menunjukkan bahwa perilaku bullying memiliki 
akibatlangsungyang sama seperti efektidaklangsung dalam kenakalan, yaitu pelampiasan amarah. Hubungan positif yang ditimbulkan akibat perilaku bullying dalam kenakalan sangat kuat, sehingga hubungan antara perilaku bullying dan kenakalan menjadi semakin kuat dibandingkan dengan hubungan korban bullying dan kenakalan. Akibat tidak langsung dari perilaku bullying dalam kenakalan melalui pelampiasan amarah meningkat. Penelitian ini menunjukkan adanya hubungan positif antara perilaku bullying dan luapan kemarahan. Oleh sebab itu, para remaja yang bergabung dalam suatu kelompok dan menyakiti seseorang atau sekelompok yang lain, akan menjadi remaja yang sama dengan remaja yang memiliki luapan kemarahan. Kesimpulannya, luapan kemarahan secara langsung berhubungan dengan perilaku delinkuen remaja.

Dunia remaja seringkali membuat pusing orang tua, para remaja memiliki keingintahuan yang tinggi. Akhirnya seringkali para remaja terjerumus kedalam lubang kehancuran.Begitupula remaja di sekolah, tidak jauh berbeda. Mereka membolos, berkelahi, mengamuk, menggaggu, dan tidak mau belajar. Ini juga menjadi masalah di kalangan remaja. mereka merasa sudah mampu dan mengetahui segalanya dan maunya dianggap sama dengan orang dewasa. Di sinilah diperlukan perhatian dan didikan orang tua yang memiliki sikap tegas, artinya tegasitu sendiri tidak selalu identik dengan kekerasan atau berimbas penganiayaan, melainkan adanya komunikasi dan diskusi yang baik, terbuka dan menyenangkan sehingga anak tidak sungkan menceritakan apa yang telah terjadi pada dirinya baik dengan dirinya sendiri maupun teman dan lingkungan tempat mereka berada selain itu mereka merasakan adanya kedamaian bathin. Permasalahan di atas yang menjadi ketertarikan penulis untuk meneliti kedamaian bathin remaja dengan perilaku delinkuen dengan persfektif psikologi Islam. Penelitian ini menggunakan subjek 10 remaja de- likuen (laki-laki). Dengan usia remaja 14 tahun. Penelitian ini menggunakan teknik observasi dan interview secara mendalam, menggunakan panduan wawancara yang telah dipersiapkan oleh peneliti secara bertahap, wawancara dilakukan secara intensif pada remaja yang terindikasi delikuen dan bertempat di sekolah menengah pertama di Tangerang Selatan.

\section{Literature Review \\ Kedamaian Bathin}

kedamaian bathin sebagai pikiran yang tidak hanya adanya konflik mental, kedamaian bathin jiwa tidak hanya adanya konflik moral; merupakan sebuah kebahagiaan sebagai suatu kesenangan untuk memiliki apa yang kita miliki; adanya kepuasan dari apa yang kita miliki. Adanya analisis konsep kedamaian bathin berdasarkan atribut kedamaian bathin seperti surga, perdamaian, keamanan, detachmant dari keinginan dan emosi yang berlebihan; dan penerimaan situasi yang tidak dapat diubah. Sebagai hasil dari analisis ini, definisi kedamaian bathinsebagai pengalaman spiritual kedamaian batin yang independen dari peristiwa eksternal hal tersebut diatas menurut Pfau (dalam Roberts, K.T dan Fitzgerald, L., 1991).

Kedamaian bathin merupakan bingkai kebahagiaan dalam hidup. Kedamaian bathin atau kenyamanan itu berasal dari dalam diri dan bisa diciptakan sendiri. Kedamaian bathin tidak datang atau dipengaruhi oleh dan di luar diri seperti : orang lain atau situasi kondisi. Kedamaian bathin itu adalah hasil dari kepribadian seorang dalam mengelola dan mengkondisikan dirinya dari berbagai situasi. Aura atau pancaran kedamaian bathin itu sama halnya dengan aura syukur. Kepositifannya bisa menyebar kepada orang-orang disekelilingnya tanpa ada hantaran. Oates $(1979,1987)$ dijelaskan sebagai respon internal untuk menghentikan gerakan cepat pada jantung. Kedamaian bathin merupakan bagian 
dari kedamaian bathin pikiran untuk beberapa waktu, namun kedamaian bathin tampaknya lebih dari ketenangan pikiran.

Model konseptual berikutnya dikembangkan oleh Roberts dan Whall (1996) menyatakan bahwa kedamaian bathinadalah belajar, emosi positif yang menurunkan stres yang dirasakan dan meningkatkan kesehatan. Kedamaian bathina dalah kedamaian yang melampaui segala pemahaman. Whitfield (1984) mengklasifikasikan kedamaian bathin sebagai spiritual yaitu berkaitan dengan nilai, makna, cinta, tujuan dan hubungan. Dossey, Keegan, Guzzetta, \& Kolkmeir (1988) mendefinisikan setelah penelitiannya bahwa kedamaian bathinsebagai pengalaman spiritual kedamaian bathin, kepercayaan, dan keterhubungan yang secara independen dari peristiwa eksternal. Spiritual seperti yang digunakan di sini mengacu pada nilai, makna, tujuan hidup, hubungan dan balik ke dalam sifat-sifat luhur manusia (alami) seperti kejujuran, cinta, dan semangat. Spiritual tidak dapat dikaitkan dengan agama formal.

Spiritualitas adalah membangun multidimensi yang telah didefinisikan dalam banyak cara dan umumnya dipahami terkait tetapi berbeda dari religiusitas. Keyakinan agama yang terkait dengan tradisi iman tertentu. Komitmen untuk agama mungkin melibatkan kepatuhan terhadap keyakinan tertentu (ideologi), larangan agama (menghindarialkohol, dan obat-obatanyang dilarang) dan komitmen dalam suatu ikatan keagamaan yang berusaha untuk menjadi inspirasi, hormat, kagum, bermakna, dan bertujuan bahkan pada mereka yang tidak percaya pada Tuhan. Dimensi spiritual harus selaras dengan alam semesta, berusaha untuk menjawab tentang yang tak terbatas dan fokus ketika stres, sakit fisik atau kematian.

Spiritualitas juga telah digambarkan sebagai sebuah proses dan perjalanan suci(Mische, 1982), esensi atau prinsip hidup seseorang (Collinton
1981). Spiritualitas dipahami sebagai konstruk luas yang mencakup banyak dimensi termasuk ketenangan. Konsep kedamaian bathindan hubungan dengan spiritualitas, kesehatan, dan kesejahteraan pertama kali muncul dalam literatur keperawatan di pertengahan 1960-an ketika itu diidentifikasi sebagai hasil penting bagi pasien yang sakit parah (Knipe, 1966).Kedamaian bathintelah didefinisikan sebagai sesuatu spiritual yang menurunkan stres dan meningkatkan kesehatan yang optimal (Roberts \& Cunningham, 1990) keadaan berkelanjutan kedamaian batin (Gerber, 1986) dan pengalaman kesehatan yang universal terkait dengan kualitas hidup (Kruse, 1999) Boyd-Wilson, Walkey dan McClure (2004) menggambarkan kedamaian bathinsebagai kualitas spiritual yang melibatkan kedamaian batin meskipun perubahan-perubahan dan bahkan perasaan; sehingga seseorang dapat merasakan kesedihan sebelum menjadi tenang.

Zakiah (1996) yang menentukan kedamaian bathindan kebahagiaan hidup adalah kesehatan mental. Orang yang sehat mentalnya tidak akan lekas putus asa, pesimis, atau apatis, karena ia dapat menghadapi semua rintangan atau kegagalan dalam hidup dengan tenang dan wajar dan menerima kegagalan itu sebagai pelajaran yang akan membawa kesuksesan nantinya. Perasaan tenang harus terwujud dan sekaligus menjadi cerminan dari kedamaian bathindalam hati, bathin, dan pikiran. Apabila hati seseorang merasa gelisah, cemas, atau bahkan takut, maka dapat dipastikan pikirannya pun akan merasakan hal yang sama. Menurut hasil penelitian Lee, et al. (2011) mendengarkan musik dapat secara signifikan menurunkan tingkat kecemasan pada pasien sebelum menjalankan operasi. Pada frekuensi domain parameter HRV dapat menjadi indikator untuk merubah kondisi kecemasan pada level sebelum pasien operasi. Penelitian lainnya Yan Liu \& Marcia A (2015) ditemukan tentang fakta-fakta secara praktis yang dapat 
mensupport melalui terapi musik untuk mengurangi rasa sakit pasca operasi dan menurunkan tekanan darah dan perasaan sakit pada pasien setelah pembedahan operasi di China.

Sejalan dengan di atas, penelitian Rosinah, et al (2014) terapi murottal dapat membantu menurunkan gejala tingkat hiperaktivitas dan impulsivitas pada anak ADHD. Pada tahapan ini subjek penelitian diamati dalam rentang gejala yang alamiah. Rata-rata gejala yang muncul enam gejala dari Sembilan gejala. Gejala yang sering muncul adalah subjek melakukan gerakan seolah-olah digerakkan oleh mesin sehingga subjek tidak bisa diam, dan memaksakan kehendak karena tipe anak ini tidak bisa menunggu dengan lama. Pergaulan subjek penelitian dengan teman-temannya terbilang cukup harmonis walau terkadang subjek penelitian sering dimanfaatkan oleh teman-temannya untuk melaksanakan pekerjaan yang lain. Hasil dari tahap intervensi adalah subjek penelitian selama proses intervensi pada pertemuan pertama dapat duduk dengan tenang kurang lebih sekitar delapan menit. Dilanjutkan pada hari kedua subjek dapat duduk dengan tenang selama kurang lebih sepuluh menit. Keadaan subjek ketika diberikan sebuah perlakuan mengalami kondisi yang berbeda-beda. Diantaranya perbedaan kondisi itu seperti keadaan mengantuk, sedang sakit, dan ada berbagai permasalahan yang dihadapi ketika melaksanakan intervensi. Pada sesi keempat intervensi, subjek penelitian mengantuk sehingga sedikit kesulitan dalam melakukan intervensi namun ketika subjek terkantuk-kantuk, subjek penelitian masih bisa mendengarkan bacaan murottal yang diputar untuk intervensi sedikit banyak sudah meresap kedalam alam bawah sadar subjek penelitian. Hasil penelitian ini menunjukkan adanya pengaruh terapi murottal terhadap menurunnya gejala yang timbul dari subjek penelitian. Pada awalnya gejala yang muncul masih berada pada tahap observasi ked- ua atau baseline II gejala tersebut sudah menurun menjadi tiga gejala yang muncul. Walaupun frekuensi yang muncul tidak stabil. Dapat disimpulkan bahwa terapi murottal memiliki hubungan terhadap perilaku hiperaktif impulsive pada anak ADHD. Terapi murottal bersifat menenangkan anak ADHD. Ketika diperdengarkan bacaan murottal dalam keadaan normal, secara perlahan subjek penelitian berangsur untuk tenang. Jika dilatih untuk melafalkan bacaan al-Qur'an, subjek penelitian sedikit memperbaiki artikulasi dan pelafalan. Terapi murottal direkomendasikan untuk meredakan perilaku anak ADHD.

Berdasarkan penelitian di atas dapat disimpulkan bahwa musik, terapi murottal, terapi dzikir, menjadi media untuk dapat menenangkan seseorang ketika dalam kondisi cemas, gelisah, agresif, hiperaktif dan impulsivitas, karena kedamaian bathinsebagai kualitas spiritual yang melibatkan kedamaian batin meskipun perubahan-perubahan dan bahkan perasaan; sehingga seseorang dapat merasakan kesedihan sebelum menjadi tenang.

\section{Perilaku Delinkuen}

Perilaku delinkuen mencerminkan perilaku negatif, menentang, tidak patuh dan perilaku bermusuhan terhadap otoritas. Yang menjadi hal terpenting dari kedelinkuensian adalah perilaku melanggar hak orang lain serta norma sosial yang dilakukan secara berulang dan terus menerus. Perilaku delinkuen adalah perilaku yang dimiliki seorang anak muda yang mereka umumnya berada di bawah usia 18 tahun, dimana sifat dari perilaku tersebut adalah melanggar norma, atau mengandung dosa serta identik dengan perbuatan yang salah, atau perilaku yang mengandung unsure pelanggaran, serangan, kesalahan atau kejahatan yang relatif minor melawan undang-undang legal, khususnya dilakukan oleh anak-anak muda yang belum dewasa. Kenakalan biasanya termasuk gangguan perilaku 
dan perilaku antisosial. Dengan kata lain, dari perspektif psikologis, perilaku delinkuen adalah gangguan perilaku atau bentuk dari perilaku anti sosial yang ekstrim (Bartol, dkk., 2014).

Penelitian lainnya menyebutkan bahwa kenakalan remaja pada kelompok imigran seperti kelompok Hmong melaporkan Hmong yang paling berakulturasi dan telah menghadapi masalah terkait dengan penyesuaian (Rumbaut, 1995). Kenakalan remaja identik terjadi pada kelompok dengan lingkungan yang miskin, seperti pada penelitian (Thao \& Preitfer, 2004) bahwa mereka remaja nakal muncul dari kelompok-kelompok etnis yang paling miskin di Amereika Serikat, dengan pendapatan perkapita pada tahun 1999 di bawah $\$ 7.000$. Peneliti pun menunjukkan bahwa keluarga Hmong, dibandingkan dengan keluarga imigran lainnya, telah mengalami stress akulturasi tinggi dan telah melaporkan konflik antara orang tua dan anak (Portes \& Rumbaut, 2004). Berdasarkan hasil penelitian bahwa stress akulturatif dan konflik orang tua- remaja telah terbukti memainkan peran penting dalam pembentukan kenakalan remaja (Bankston \& Caldas, 1996 ; Mcloyd, 1998; Zhou \& Bankston, 1998).

Penelitian selanjutnya juga mengatakan bahwa remaja atau anak yang dibesarkan dalam keluarga yang sama identiknya dengan pengalaman yang telah diterimanya sehingga mempengaruhi satu sama lainnya dalam perilaku delinkuen dan tentunya berkolaborasi terhadap kejahatan (Slomkowski, et al. 2001). Penelitian lainnya menunjukkan bahwa remaja nakal dipengaruhi oleh lingkugan keluarga dan secara langsung mereka belajar satu sama lain, adanya hubungan persaudaraan yang rendah sehingga munculnya kepribadian yang kenakalan dan membentuk kepribadian (Ahern, dkk, 1982; Rowe, dkk, 1992). Dapat disimpulkan bahwa remaja dengan perilaku delinkuen dipengaruhi oleh pribadi dan ligkungan keluarga yang dimulai dari ketidakharmoniasan antar saudara dalam keluarga se- hingga dapat menimbulkan ketidaknyamanan pada diri remaja dan akhirnya mereka melakukan sesuatu yang sifatnya mengganggu. Perilaku delinkuen dapat dipicu oleh perlakuan orangtua yang kebanyakan membedakan anak yang satu dengan lainnya. Selain itu, anak-anak dengan menerima perbedaan konflik dan memiliki control yang lebih dari orang tua dapat juga terlibat dalam perilaku delinkuen (KJ Conger \& Conger, 1994; Daniels,dkk, 1985). Demikian pula remaja yang memiliki perbedaan bersaudara menunjukkan bahwa remaja yang dianggap diri mereka sebagai yang lebih dibebani dari saudara lainnya dan kedekatan terhadap ibu terganggu akan menunjukkan perilaku delinkuen (Daniels, et al. (1985).

Dapat disimpulkan bahwa perilaku delinkuen dapat diperoleh melalui lingkungan internal maupun eksternal remaja. Penelitian Le, Thao N. \&Gary Stockdale (2010) bahwa orang yang individualis cenderung akan berhenti untuk terlibat dalam kenakalan ketika mereka menerapkan peran baru di kehidupan mereka seperti bekerja dan membangun hubungan berpasangan. Penelitian juga menunjukkan di antara keturunan remaja Afika-Amerika dan kulit putih, angka kenakalan cenderung tinggi pada masa pra-remaja, mencapai puncaknya ketika di antara pertengahan dan akhir remaja, dan akan menurun di akhir usia remaja. Penelitian tersebut menyetujui bahwa perilaku delinkuen remaja sebanding dengan teori ekologi yang diungkapkan oleh Brofenbrenner, yang menjelaskan bahwa perilaku delinkuen remaja berbentuk seperti peluru. Lingkungan sangatlah berpengaruh terhadap diri remaja khususnnya pertemanan. Pertemanan pada remaja membentuk karakter dan kehidupan yang akan dijalaninya. Padahal peran orang tua turut memberi pengaruh besar pada keputusan yang diambil para remaja dalam menentukan kehidupannya. Para orang tua banyak memberikan pengaruh pada usia pertengahan 
50

NUANSA Vol. XII, No. 1, Juni 2019

remaja dan akhir usia remaja.

Pendapat Walters (2013) bahwa orangtua yang tidak peduli kepada anak lelakinya akan membuat remaja laki-laki tersebut terlibat dalam kenakalan, sedangkan orangtua remaja puteri yang permisif membuat anak perempuannya melakukan kenakalan pada usia dewasanya. Peneliti mencatat bahwa salah satu orangtua yang menerapkan peraturan disiplin mampu menurunkan resiko kenakalan pada anaknya, dibandingkan dengan dua orangtua yang tidak mempedulikan anaknya maka risiko anaknya terlibat dalam kenakalan semakin tinggi. Peran orangtua dijabarkan sebagai pembentuk pola pandang dan muatan nilai potensial sebagai proses remaja menuju pribadi yang dewasa dengan melihat pola asuh yang demokratis, otoriter, permisif, dan abai, serta pengaruhnya pada keputusan yang mereka buat di masa yang akan datang. Perilaku delinkuen remaja biasanya disebabkan oleh beberapa variable yang berhubungan dengan perilaku-perilaku yang telah terjadi dalam rentang waktu tertentu. Beberapa faktor yang dijadikan pedoman dalam menentukan kemajemukan perilaku terhadap remaja adalah faktor keterlibatan remaja dalam kehidupan seksual mereka seperti pertama kali mereka melakukan hubungan seksual, kemudian hubungan remaja dengan sekolahnya, serta keterlibatan remaja dalam mengkonsumsi minuman beralkohol. Kehidupan remaja sangatlah rentan melihat beberapa ulasan di atas, perlu banyak kontribusi dari semua pihak baik keluarga, sekolah, masyarakat dan pemerintah. Kontribusi di sini adalah perlindungan dan pencegahan secara terus menerus sehingga dapat meminimalisir angka kenakalan remaja di Indonesia. Karena banyak faktor yang menyebabkan kenakalan pada remaja.

Penelitian Lanza, Stephanie T., dkk (2013) menyebutkan bahwa yang menjadi faktor resiko dalam kenakalan remaja adalah diri sendiri, pertemanan, keluarga, sekolah dan tingkat komu- nitas. Selain itu, yang menjadi indikator dalam penelitian ini adalah (1) kekompakan komunitas, (2) aturan dan ketersediaan obat-obatan/ senjata api dalam komunitas,(3) dukungan sekolah untuk kegiatan-kegiatan sosial,(4) keutuhan keluarga, (5) akibat yang ditimbulkan keluarga, (6) pertemanan yang tidak ramah, (7) sikap tidak ramah, dan (8) perilaku beresiko. Ada beberapa tindakan pencegahan yang dapat dilakukan meliputi lima aspek yang saling mendukung, yaitu : komunitas, sekolah, keluarga, teman, dan diri sendiri.

Penelitian tentang perlindungan keluarga memiliki nilai yang sangat besar pada tingkat rendahnya penggunaan zat-zat terlarang pada remaja. Sedangkan keluarga yang tingkat kepedulian terhadap remaja rendah akan menyebabkan peningkatan resiko kenakalan di sekolah. Oleh sebab itu, diperlukan adanya pengetahuan tentang kemajemukkan populasi dalam faktor-faktor dominan pada pengganggulangan resiko kenakalan remaja dan perlindungan terhadap remaja. Faktor kemajemukan di sini dapat bermacam-macam karena kondisinya ada di masyarakat. Sebut saja latar belakang keluarga, pola asuh dan lingkungan sosial. Seperti dalam penelitian Crespi, Tony D., dkk (1996) bahwa latar belakang keluarga, pola asuh dan lingkungan sosial menjadi faktor penting bagi pembunuh remaja untuk memperbaki mereka agar tidak menjadi pembunuh dan ini menjadi penelitian yang masih menarik bagi para ilmuan dan peneliti. Mendle, Jane., dkk dalam penelitiannya ( 2011) bahwa untuk keduaremajamudadantua, secara umum yang mendasariperilaku seksualdankenakalan yaitu adanya pengaruh genetik Pada remajayang lebih tua, kegiatan seksualyangterjadidalam hubungan romantisdiprediksitingkatanya yang lebih rendahdarikenakalan, baiksecara cross-sectionaldanlongitudinal, sedangkanaktivitas seksual padanon-romantis tingkat hubungandiperkirakanlebih yang tinggi 
tingkat pelanggarannya.

Dapat disimpulkan bahwa remaja dengan perilaku delinkuen membutuhkan pembinaan dan dukungan yang memberikan mereka kedamaian bathin diantaranya kelima aspek yang perlu mendukung mereka adalah komunitas, sekolah, keluarga, teman, dan diri sendiri.

\section{Kedamaian Bathin dan Remaja dengan Peri- laku Delinkuen}

Bicara remaja yang sangat menarik adalah kenakalannya. Masa remaja adalah waktu dimana kesadaran sosial seseorang akan semakin tinggi dan masa munculnya tekanan sosial di setiap harinya, sehingga remaja dianggap sebagai populasi yang rentan atau vulnerable untuk mengalami masalah. Berbagai masalah dapat terjadi pada masa remaja, karena tingkah laku remaja yang masih belum mampu menyesuaikan diri dengan berbagai tuntutan dari lingkungan (Willis, 2005). Remaja merupakan tahap transisi dari anak-anak menuju kedewasan (13-18 tahun), peran dari lingkungan sekitarnya dapat mempengaruhi dalam pencarian identitas diri remaja tersebut. Masa remaja bukan hanya tampakmelalui perubahan fisik tetapi juga terjadi perubahan psikis seorang anak. Banyak faktor yang mempengaruhi tingkah laku para remaja yang dapat menjerumuskan para remaja kedalam pergaulan bebas dengan tindakan kenakalannya. Kenakalan remaja bisa disebut juvenile berasal dari bahasa latin juvenilis, yang artinya anak-anak, anak muda, sifat khas pada periode remaja, sedangkan delinquency berasal dari bahasa latin "delinquere" yang berarti terabaikan, menjadi jahat, nakal, anti sosial, criminal, pelanggaran aturan, perilaku jahat atau kenakalan anak-anak muda, merupakan gejala sakit (patologis) secara sosial (Kartono, 2006). Dengan adanya gejala sakit yang muncul tentu membutuhkan penanganan khusus agar mereka terbebas dari tindakan yang telah merugikan lingkungan. Penanganan-pen- angan khusus yang dilakukan mampu memberikan kedamaian terhadap bathin remaja dengan perilaku delinkuen.

Remaja delikuen membutuhkan kedamaian bathin dan ini memerlukan kontribusi yang baik dari semua pihak. Hikmah (2009) dalam penelitiannya menyimpulkan bahwa dalam Al-Qur'an an-Nafs al-Mutmainnah didorong oleh faktor internal yaitu daya kalbu manusia yang memiliki sifat ilahiyah. Artinya jika kalbu berkuasa maka ia mampu memberikan garansi kedamaian bathindan keimanan. Faktor eksternal berupa penjagaan diri dan hidayah dari Allah SWT. Hidayah (petunjuk) dari Allah SWT sangat membantu manusia dalam menemukan jati dirinya. Tanpa hidayah dari Allah SWT manusia akan sulit menemukan jati dirinya.

Penelitian lainnya, Mireault (2007) menemukan bahwa kecemasan adalah salah satu dari banyak variabel yang terkait dengan amukan, dan temuan ini menyiratkan bahwa orang tua dan pengasuh harus mempertimbangkan yang mungkin mencerminkan kecemasan anak yang mendasarinya, kebingungan, atau stres. Penelitian lainnya mendukung terkait dengan emosi, menurut Fried (2011), penelitian ini mengungkapkan kondisi suasana di kelas terkait apa yang saat ini diketahui tentang hubungan antara emosi dan belajar, sehingga membangun sebuah kasus untuk dapat menjawab mengapa pentingnya ketenangan. Selanjutnya, dalam rangka untuk lebih mengembangkan pemahaman tentang regulasi emosi, sistem klasifikasi diuraikan dan temuan penelitian yang berkaitan dengan penggunaan strategi regulasi emosi disajikan. Akhirnya, beberapa masalah pendidikan yaitu praktisi pedagogis yang meningkatkan pengembangan regulasi emosi yang dapat selesaikan dengan baik. Sehingga ditemukan dan disimpulkan bahwa emosi memiliki pengaruh yang signifikan pada pembelajaran dan sekolah adalah proses emosional, ada kalanya siswa dan guru 
perlu menerapkan strategi regulasi emosi di dalam kelas untuk mencapai sebuah ketenangan.

Jika kita lihat bahwa kedamaian batin mengacu pada suatu keadaan mental dan spiritual damai, dengan pengetahuan yang cukup dan pemahaman untuk menjaga diri sendiri yang kuat dalam menghadapi perselisihan atau stres. Menjadi damai dianggap oleh banyak orang bagaimana untuk menjadi sehat (homeostasis). Kedamaian batin dianggap sebagai keadaan kesadaran atau pencerahan yang dapat dilakukan melalui berbagai bentuk pelatihan, seperti doa, meditasi, tai chi atau yoga. Banyak praktik spiritual menyebut kedamaian ini sebagai pengalaman untuk mengetahui diri sendiri. Menemukan kedamaian batin sering dikaitkan dengan tradisi seperti Hindu dan Budha.

Tendhar (2014) menyebutkan kedamaian batin dapat digambarkan dengan cara yang berbeda berdasarkan pemahaman individu tapi di sini mengacu pada disposisi mental yang bebas dari pikiran dan emosi dengan kekuatan internal, kestabilan, dan kedamaian yang memperhatikan kondisi eksternal. Tan (2012) Kedamaian bathin adalah keadaan pikiran yang bebas dari penderitaan. Menurut Saulson (1999) Kedamaian bathin adalah pengalaman subyektif yang berkaitan dengan ketenangan berhubungan erat dengan psikologis. Melalui relaxasi yang merupakan salah satu cara dalam penelitian yang akan menimbulkan kedamaian bathin.

Jimenez, et al (2014) Sebagaimana telah dikatakan, pengertian tentang kedamaian bathin/ makna dalam kehidupan dihubungkan dengan self rated health (SRH), tetapi agama tidak menjadi sumber kesejahteraan spiritual (spiritual well-being). Ujian yang terdapat pada kesejahteraan spiritual pada subskala ditetapkan pada beberapa pengetahuan-pengetahuan. Ketika kedamaian menjadi item subskala yang terkandung didalamnya tentang perasaan damai, memiliki pemikiran untuk kehidupan, keinginan untuk produktif dalam hidup, memiliki keinginan/ tujuan untuk hidup, subskala keyakinan itemitemnya yang terkandung diantaranya kesenangan, kekuatan yang tersimpan dalam keyakinan/ agama. Penjelasan bahwa pengertian kedamaian dan maknanya adalah hasil dari salah satu keyakinan beragama. Oleh karena itu, keyakinan secara signifikan tidak terkait dengan SRH pada kedamaian bathin akibat dari hasil penelitian ini. Interpretasi ini merupakan ketetapan dengan adanya bukti-bukti dari pengalaman salah satu penulis sebagai pemberi support pada penderita kanker. Yang mana dalam Latinas mendekati pada penerimaan diagnosis mereka, sebagian dua dari mereka percaya pada agama. Untuk beberapa group budaya, perasaan ini diterima dengan tenang dalam menghadapi diagnosis kanker secara langsung pada kepercaayaan perempuan dalam beragama dan latarbelakang budaya, dan dapat mewakili kemandirian pada konstrak budaya terhadap gangguan fatalism. Fatalism ini sering sebagai karakteristik yang menghalangi untuk perilaku kesehatan yang positif.

Begitu pula dengan perilaku delinkuen merupakan bagian dari masalah yang dihadapi oleh masyarakat, khususnya remaja. Perilaku delinkuen pada remaja dalam tulisan ini adalah remaja yang di sekolah dan bermacam-macam polah yang dilakukan, diantaranya membolos dengan berulang-ulang hingga mendapatkan skors dari sekolah, mengganggu teman sebaya di sekolah hingga membuat siswa tidak nyaman dalam belajar dan ini terjadi setiap hari, mengamuk di sini memunculkan perilaku yang menganggu kenyamamanan belajar siswa lainya dan ini dilakukan terus menerus, dan merusak di sini adalah sering melakukan pengrusakan pada fasilitas sekolah. Semua itu muncul dengan sebab yang berbeda-beda seperti adanya masalah dan kecemasan dengan kondisi di keluarga sehingga tidak terkendalikan emosi dan di sekolah akhirnya mengamuk, merusak dan menyakiti orang 
lain. Remaja delikuen membutuhkan kedamaian bathin dan ini memerlukan kontribusi yang baik dari semua pihak. (Hikmah 2009) dalam penelitiannya menyimpulkan bahwa dalam Al-Qur'an an-Nafs al-Mutmainnah didorong oleh faktor internal yaitu daya kalbu manusia yang memiliki sifat ilahiyah. Artinya jika kalbu berkuasa maka ia mampu memberikan garansi kedamaian bathin dan keimanan. Faktor eksternal berupa penjagaan diri dan hidayah dari Allah SWT. Hidayah (petunjuk) dari Allah SWT sangat membantu manusia dalam menemukan jati dirinya. Tanpa hidayah dari Allah SWT manusia akan sulit menemukan jati dirinya. Begitu pula dengan kedamaian bathin yang berasal dari dalam diri dan bisa diciptakan sendiri. Kedamaian bathin tidak datang atau dipengaruhi oleh dan di luar diri seperti : orang lain atau situasi kondisi. Kedamaian bathin itu adalah hasil dari kepribadian seorang dalam mengelola dan mengkondisikan dirinya dari berbagai situasi. Aura atau pancaran kedamaian bathin itu sama halnya dengan aura syukur. Kepositifannya bisa menyebar kepada orang-orang disekelilingnya tanpa ada hantaran. Oates $(1979,1987)$ dijelaskan sebagai respon internal untuk menghentikan gerakan cepat pada jantung. Hasil penelitian ini memberikan kesan penyembuhan diri pada kanker dapat mendorong pada penilaian kesehatan diri meskipun komponen-komponen kesejahteraan pada spiritual terkait pada kedamaian bathin dan makna dalam satu kehidupan. Penemuan-penemuan yang sesuai dengan studi sebelumnya yang telah ditemukan melalui penemuan yang menguntungkan/bermanfaat (rasa memaknai setelah menderita kanker) telah berhubungan dengan kesehatan yang lebih baik.

Definisi kedamaian bathin menjelaskan bahwa seseorang dalam keadaan berpikir dan memiliki kebebasan dari masalah yang di deritanya. Adanya kesedihan dan rasa sakit yang diderita oleh remaja tentunya membuat studi dan penelitian ini memberikan gambaran secara khusus apa yang dialami remaja yang terindikasi perilaku delinkuen. Dossey (1988) mendefinisikan setelah penelitiannya bahwa ketenangan sebagai pengalaman spiritual kedamaian bathin, kepercayaan, dan keterhubungan yang secara independen dari peristiwa eksternal. Spiritual seperti yang digunakan di sini mengacu pada nilai, makna, tujuan hidup, hubungan dan balik ke dalam sifat-sifat luhur manusia (alami) seperti kejujuran, cinta, dan semangat. Spiritual tidak dapat dikaitkan dengan agama formal.

Spiritualitas adalah membangun multidimensi yang telah didefinisikan dalam banyak cara dan umumnya dipahami terkait tetapi berbeda dari religiusitas. Keyakinan agama yang terkait dengan tradisi iman tertentu. Komitmen untuk agama mungkin melibatkan kepatuhan terhadap keyakinan tertentu (ideologi), larangan agama (menghindarialkohol, dan obat-obatan yang dilarang) dan komitmen dalam suatu ikatan keagamaan yang berusaha untuk menjadi inspirasi, hormat, kagum, bermakna, dan bertujuan bahkan pada mereka yang tidak percaya pada Tuhan. Dimensi spiritual harus selaras dengan alam semesta, berusaha untuk menjawab tentang yang tak terbatas dan fokus ketika stres, sakit fisik atau kematian. Spiritualitas juga telah digambarkan sebagai sebuah proses dan perjalanan suci (Mische, 1982), esensi atau prinsip hidup seseorang (Collinton 1981).

Spiritualitas dipahami sebagai konstruk luas yang mencakup banyak dimensi termasuk kedamaian. Konsep kedamaian bathindan hubungan dengan spiritualitas, kesehatan, dan kesejahteraan pertama kali muncul dalam literatur keperawatan di pertengahan 1960-an ketika itu diidentifikasi sebagai hasil penting bagi pasien yang sakit parah (Knipe, 1966). Menurut Zakiah (1996) yang menentukan kedamaian bathin dan kebahagiaan hidup adalah kesehatan mental. Orang yang sehat mentalnya tidak akan lekas putus 
54 NUANSA Vol. XII, No. 1, Juni 2019

asa, pesimis, atau apatis, karena ia dapat menghadapi semua rintangan atau kegagalan dalam hidup dengan tenang dan wajar dan menerima kegagalan itu sebagai pelajaran yang akan membawa kesuksesan nantinya. Perasaan tenang harus terwujud dan sekaligus menjadi cerminan dari kedamaian bathin dalam hati, bathin, dan pikiran. Apabila hati seseorang merasa gelisah, cemas, atau bahkan takut, maka dapat dipastikan pikirannya pun akan merasakan hal yang sama. Menurut hasil penelitian Lee, (2011) mendengarkan musik dapat secara signifikan menurunkan tingkat kecemasan pada pasien sebelum menjalankan operasi. Pada frekuensi domain parameter HRV dapat menjadi indikator untuk merubah kondisi kecemasan pada level sebelum pasien operasi. Penelitian lainnya Liu (2015) ditemukan tentang fakta-fakta secara praktis yang dapat mensupport melalui terapi musik untuk mengurangi rasa sakit pasca operasi dan menurunkan tekanan darah dan perasaan sakit pada pasien setelah pembedahan operasi di China.

Studi yang telah dilakukan oleh Tan (2012) tentang kedamaian bathin dan menghasilkan dimensi-dimensi kedamaian bathin diantaranya : (1) Kedamaian fisik; (2) Kedamaian psikologis; (3) Kedamaian sosial; dan (4) Kedamaian spiritual. Selain dimensi-dimensi yang dihasilkan oleh peneliti, ditemukan juga 6 kategori tentang kedamaian bathin yaitu (1) Kesadaran diri; (2) Berpikir positif; (3) Berperasaan positif; (4) Berperilaku positif; (5) Bersikap positif; dan (6) Pengaturan diri/mengatur diri.

Dapat disimpulkan bahwa kedamaian bathin sangat diperlukan oleh remaja yang terindikasi perilaku delinkuen melalui pendampingan semua pihak agar mereka mampu berpikir, mengatur diri dan bertindak secara positif dalam kehidupan sehari-hari.

\section{Remaja dengan Perilaku Delinkuen dalam Persfektif Psikologi Islam}

Saat ini banyak orang tua maupun pendidik yang sangat khawatir terhadap perkembangan remaja terkait dengan moral dan nilai-nilai kehidupan yang mulai bergeser. Kejadian kekerasan kerap terjadi dikalangan remaja dengan aksi mereka baik berupa tawuran dan perilaku delinkuen lainnya yang dapat merugikan orang lain. Dalam Al-Qur'an ada beberapa istilah yang menunjukkan pada kekerasan. Secara istilah, ada beberapa kata di dalam Al-Qur'an yang tampak menunjuk pada kekerasan. ada sekitar 12 ayat yang berhubungan dengan kata permusuhan (i'tada-ya'tadi), ada 39 ayat yang berhubungan dengan kedzaliman (zolama, yazlimu), ada 24 ayat yang berhubungan dengan pembunuhan (qotala-yaqtulu); ada 39 ayat yang berhubungan dengan perbuatan yang merusak (fasada-yafsudu atau 'asyiya-ya'syau), dan ada 39 ayat yang berhubungan dengan cacian (istahzaa-yastahziu). Rahman (2013)

Ayat-ayat tersebut di atas, secara umum, menunjukan bahwa Islam merupakan agama yang melarang kekerasan. bagi Islam, membunuh seseorang yang bukan karena membunuh orang lain atau karena membuat kerusakan di muka bumi, sama dengan membuuh semua orang yang ada di muka bumi (QS Al-Maidah [5]: 32). Ini jelas adanya larangan secara tegas. Sementara remaja sendiri juga sering dihadapkan pada dilema-dilema moral sehingga remaja merasa bingung terhadap keputusan-keputusan moral yang harus diambilnya. Walaupun di dalam keluarga mereka sudah ditanamkan nilainilai, tetapi remaja akan merasa bingung ketika menghadapi kenyataan ternyata nilai-nilai tersebut sangat berbeda dengan nilai-nilai yang dihadapi bersama teman-temannya maupun di lingkungan yang berbeda. Pengawasan terhadap tingkah laku oleh orang dewasa sudah sulit dilakukan terhadap remaja karena lingkungan remaja sudah sangat luas. Pengasahan terhadap hati nurani sebagai pengendali internal perilaku 
remaja menjadi sangat penting agar remaja bisa mengendalikan perilakunya sendiri ketika tidak ada orang tua maupun guru dan segera menyadari serta memperbaiki diri ketika dia berbuat salah.

Pada tinjauan teori perkembangan, usia remaja adalah masa saat terjadinya perubahanperubahan yang cepat, termasuk perubahan fundamental dalam aspek kognitif, emosi, sosial dan pencapaian (Fagan, 2006). Sebagian remaja mampu mengatasi transisi ini dengan baik, namun beberapa remaja bisa jadi mengalami penurunan pada kondisi psikis, fisiologis, dan sosial. Beberapa permasalahan remaja yang muncul biasanya banyak berhubungan dengan karakteristik yang ada pada diri remaja. Dapat disimpulkan bahwa perkembangan remaja baik secara emosi, fisik dan kognitif akan terus berproses sesuai dengan perkembangan usianya dan mencari identitas diri untuk mencapai kematangan yang lebih baik. Secara bersama-sama peran keluarga terutama orangtua, pendidik, sekolah, dan masyarakat menjadi bagian dari yang mengikuti perkembangan mereka dan terus menanamkan nilai-nilai moral agar mereka tidak terjerumus menjadi generasi yang gagal.

Remaja sebagai pribadi yang rentan akan pengaruh dalam maupun luar mereka, terutama remaja dengan perilaku delinkuen merasa terkucilkan dari lingkungan keluarga maupun masyarakat. Perasaan gelisah dan ingin merubah diri menjadi lebih baik pasti ada, namun dukungan sosial sering tidak didapatkan. Ini merupakan permasalah terkait dengan kedamaian bathin, secara tidak langsung mereka kaum rentan membutuhkan perhatian dan dukungan sosial yang mampu merubah kehidupan menjadi baik. Bagi seorang muslim, masalah kedamaian bathin akan merujuk pada dua hal pokok yaitu Al-Qur'an dan Sunnah Rasul. Sebagai pondasi hidup. Al-Qur'an sendiri menjadi obat untuk salah satunya menenangkan seseorang baik secara fisik maupun psikis. Menurut Chirzin, M. (2016) bahwa Al-Qur'an adalah terapi yang disembuhkan oleh ayat-ayat Al-Qur'an. Proses penyembuhan dengan menggunakan Al-Qur'an melalui unsur bacaan, didengarkan, dipahami. Begitu pula Ilyas, Y. (2016) Al-Qur'an : terapi yang menggunakan ayat-ayat Al-Qur'an. Karena Al-Qur'an adalah obat untuk segala penyakit hati. Al-Qur'an merupakan salah satu obat yang mampu menyembuhkan segala penyakit. Qs. Al-Isra' : 17 : 82) yang artinya : Kami turunkan dari Al-Qur'an suatu yang menjadi penawar dan rahmat bagi orang-orang yang beriman dan Al-Qur'an itu tidaklah menambahkan kepada orang-orang yang zalim selain kerugian". (QS. AlIsra': $17: 82$ ).

Al-Qur'an merupakan terapi dan rahmat bagi orang-orang beriman, yakni : dapat menghilangkan sesuatu yang terdapat di dalam hati berupa berbagai penyakit seperti keragu-raguan, kemunafikan, kemusyrikan dan kesesatan. AlQur'anul Karim dapat menyembuhkan dari semua itu dan juga sebagai rahmat yang bisa didapatkan padanya keimanan, hikmah, pencarian kebaikan dan keinginan padanya. Dan hal ini tidak berlaku kecuali bagi orang yang beriman kepadanya, membenarkannya dan mengikutinya, maka ia akan menjadi terapi dan rahmat. Begitu pula dengan perilaku delinkuen merupakan bagian dari masalah yang dihadapi oleh masyarakat, khususnya remaja dalam persfektif psikologi Islam.

Sejalan dengan di atas, penelitian Rosinah, et al (2014) terapi murottal dapat membantu menurunkan gejala tingkat hiperaktivitas dan impulsivitas pada anak ADHD. Pada tahapan ini subjek penelitian diamati dalam rentang gejala yang alamiah. Rata-rata gejala yang muncul enam gejala dari Sembilan gejala. Gejala yang sering muncul adalah subjek melakukan gerakan seolah-olah digerakkan oleh mesin sehingga subjek tidak bisa diam, dan memaksakan ke- 
hendak karena tipe anak ini tidak bisa menunggu dengan lama. Pergaulan subjek penelitian dengan teman-temannya terbilang cukup harmonis walau terkadang subjek penelitian sering dimanfaatkan oleh teman-temannya untuk melaksanakan pekerjaan yang lain. Hasil penelitian ini menunjukkan adanya pengaruh terapi murottal terhadap menurunnya gejala yang timbul dari subjek penelitian. Pada awalnya gejala yang muncul masih berada pada tahap observasi kedua atau baseline II gejala tersebut sudah menurun menjadi tiga gejala yang muncul. Walaupun frekuensi yang muncul tidak stabil. Dapat disimpulkan bahwa terapi murottal memiliki hubungan terhadap perilaku hiperaktif impulsive pada anak ADHD. Terapi murottal bersifat menenangkan anak ADHD. Ketika diperdengarkan bacaan murottal dalam keadaan normal, secara perlahan subjek penelitian berangsur untuk tenang. Jika dilatih untuk melafalkan bacaan al-Qur'an, subjek penelitian sedikit memperbaiki artikulasi dan pelafalan. Terapi murottal direkomendasikan untuk meredakan perilaku anak ADHD. Berdasarkan hasil yang diperoleh dari penelitian ini, penulis dapat menyimpulkan bahwa kedamaian bathin remaja dengan perilaku delinkuen dapat diperoleh melalui pendekatan agama. Dalam hal ini pendekatan agama Islam yaitu menyediakan waktu secara intensif dengan jadwal yang ditentukan oleh pihak sekolah, untuk membaca dan mengkaji al-Qur'an kepada siswa yang dipandu oleh guru yang memiliki kapasitas dalam mengajarkan membaca al-Qur'an, disertai adanya pembahasan terkait makna surat yang terdapat di dalam al-Qur'an yang dibaca (akhlak, ibadah dan nilai-nilai kehidupan).

Untuk menjadikan remaja delikuen agar memiliki kedamaian bathin diharapkan dan harus adanya dukungan sosial dari semua pihak diantaranya (1) adanya komunikasi sekolah dengan orangtua secara intensif untuk mengetahui kondisi remaja (siswa) ketika di sekolah ; (2) du- kungan belajar yang kuat dari orangtua, guru dan sekolah sangat diharapkan karena remaja dengan perilaku delikuen memerlukan perhatian yang lebih agar proses belajar dapat berjalan dengan baik dan memiliki nilai-nilai budi pekerti yang baik pula; (3) ketersediaan fasilitas yang membantu remaja untuk mendapatkan perubahan seperti melalui pendekatan agama (membaca alQur'an dan adanya kajian dari makna al-Qur'an secara intensif) hal ini dilakukan secara bertahap dan memerlukan waktu yang cukup lama serta guru harus memiliki kesabaran dalam melaksanakan tugas ini. Ini merupakan salah satu cara yang dapat digunakan oleh kalangan masyarakat maupun pendidik. Ini juga bagian dari kajian Psikologi Islam yang dapat berkembang pesat.

\section{Daftar Pustaka}

Santrok, J. W. (2003). Adolescence (Perkembangan Remaja). Terjemahan. Jakarta: Penerbit Erlangga.

Fried. L. (2011). Teachers about Emotion Regulation in the Classroom. Australian Journal of Teacher Education, 36(3), vol 36.

(2001). Kamus Lengkap Psikologi. Jakarta : Rajawali Press

Kartono, K. (2006). Psikologi Perkembangan. Jakarta : Rineka Cipta.

Knipe, M. (1966) Serenity for a terminally ill patient. America Kournal of Nursing, 66, 22522254.

Lee, Kwo-Chen, et. al. (2011). Evidence That Music Listening Reduces Preoperative Patients' Anxiety. Biologycal Resarch for Nursing. Sagepub.com/hournalsPermissions.nav. DOI: $10.1177 / 1099800410396704$.

Liu, Y., \& Marcia. A. P. (2015). Effects of Music Therapy on Pain, Anxiety, and Vital Signs in Patients After Thoracic Surgery.Journal Complementary Therapies in Medicine : 23, 714718.

Mann, F. D., et. al. (2015). Person v.s. Environ- 
ment Interactions on Adolescent Deliquency: Sensation Seeking, Peer Deviance, and Parental Monitoring. Personality and Individual Differences, 76, 129-134.

Oates, W.E. (1979). The search for tranquility. The Journal of Pastoral Care, 12,205-209.

Rahman, Agus Abdul (2013). Psikologi sosial. Jakarta : PT Raja Grafindo Persada.

Roberts, K.T., Fitzgerald, L. (1991) Serenity : Caring with Perspective. Scholarly Inquiry for

Nursing Practice : An International Journal, Vol.5, No.2.

Roberts,K., \& Cunningham, G. (1990). Serenity concept analysis and measurement.

Educational Gerentology, 16, 577-589.

Siegel, M.S.W. Jonah A., Douglas, J. P. R. (2012). The Effect of Recovery

Coaches for Substance-Involved Mothers in Child Welfare: Impact on Juvenile Deliquency.Journal of Substance Abuse Treatment, 43, 381-387.

Sigfusdottir, I. D., Gudjonsson, G. H., Sirgudsson, J. F. (2009). Bullying and Deliquency: The Mediating Role of Anger.Personality and Individual Differences, 48, 391-396.

Fagan, R. (2006). Counseling and Treating Adolescents with Alcohol and Other Substance Use

Problems and their Family. The Family Journal: Counseling therapy For Couples and Families. Vol.14. No.4.326-333. Sage Publication diakses melalui http://tfj.sagepub.com/cgi/ reprint/14/4/326 pada 18 April 2008

Desmita. 2009. Psikologi Perkembangan. Bandung : Remaja Rosda.

Brandt, David. (2006). Delinquency, Development, and Social Policy. Yale University Press.
New Haven. London.

Mireault, Gina \& Trahan, Jessica. (2007). Tantrums and Anxiety in Early Childhood: A Pilot Study . Early Childhood Research and Practice Journal, 9, 2.

Lanza, Stephanie T., Cooper, Brittany R., Bray, Bethany C. 2014. Population Heterogeneity in The Salience of Multiple Risk Factors for Adolescent Deliquency. Journal of Adolescent Health, 54, 319-325.

Le. Thao N and Gary Stockdale. (2010). The Influence of shool demographic factors and

perceived student discrimation on delinquency trajectory in adolescence. Journal of Adolescent Health. (49), 407-413.

Lee, Gang., et al., (2011). The Relevance of Social and Cultural Contexts: Religiosity, Acculturation, and Deliquency Among Korean Catholic Adolescents in Southern California. The Social Science Journal, 49, 537-544.

Muss, R. E. , Olds, S. W. , \& Fealdman (2001). Human Development. Boston: McGraw-Hill Companies.

Rosinah, et al. (2014). Pengaruh terapi murottal terhadap tingkat hiperaktif-impulsif pada

anak attention deficit hyperactive disorder (ADHD). Universitas Negeri Yogyakarta : PELITA, Vol. IX, No.2, 141-145.

R. A. T., De Kemp., et al. (2006). Early adolescent delinquency : the role of parents and best friends. Journal of Criminal Justice and Behavior. (33), 488.

Walters, Glenn D. (2013) Deliquency, Parental Involvement, Early Adult Criminality, and Sex: Evidence of Moderated Meditation. Journal of Adolescence, 36, 777-785. 